\title{
Social Media Impact on Traditional Media: A Review on the Reason Behind the Closure of Utusan Malaysia
}

\author{
M M Kobiruzzaman ${ }^{1^{*}}$ \\ Akmar Hayati Ahmad Ghazali ${ }^{2}$ \\ Faculty of Modern Languages and Communication ${ }^{1,2}$ \\ Universiti Putra Malaysia (UPM), Malaysia ${ }^{1,2}$
}

\begin{abstract}
Social media has changed people's behaviour, attitudes, habits, lifestyles, and the process of communication. The scholar describes social media as a double-edged sword because of having a positive and negative impact on society. The aim of the paper is to identify the effects of social media on traditional media, especially on printed newspapers. Content analysis in systematic reviews has been applied to collect data from secondary sources such as journal articles, newspaper articles, government websites, and nongovernment websites. Based on the collected data, social media's positive effects on society are imparting knowledge, accelerating the communication process, building a virtual workplace, and e-commerce marketing. On the other hand, social media's adverse effects are cyberbullying, hacking, addiction, and spreading fake news. Social media have threatened the printed newspaper, and the journalist confronts challenges staying on track. The circulation of the daily printed newspaper declined gradually due to the revolution of social media and social media-based citizen journalism practising in Malaysia. Many newspapers have been compelled to cease their operation due to losing subscribers dramatically. Finally, this paper provides a review of the reason behind the closure of printed newspapers in Malaysia. Based on the discussions and the previous study, the paper presents three significant reasons behind Utusan Malaysia's closure: poor economic conditions, political crisis, social media revolution, and citizen journalism practising in Malaysia. In conclusion, few suggestions have been discussed that might help printed newspapers in Malaysia to survive in the digital era.
\end{abstract}

Keywords: Social Media; Impacts; Traditional Media; Newspapers; Citizen Journalism

*Corresponding author: M M Kobiruzzaman; Email: mmkobiruzzaman@gmail.com DOI: https://doi.org/10.37227/IJEKM-2022-01-1176

\section{Introduction}

Information and communication technologies have changed people's lifestyles and communication systems entirely (Giddens, 2018; Kobiruzzaman, Waheed, Yaakup, \& Osman, 2018). Baruah (2012) stated that social media became an essential information and communication technology platform that facilitates human communication. Social media are internet and application-based communication system that ease human 
communication through the computer and smartphone (Obar \& Wildman, 2015). Social media are also recognized as the new media that become an essential part of the modernized lifestyle. According to Kobiruzzaman (2021), it is estimated that around 3.8 billion people utilize these social media platforms, yet Facebook has become the most popular site for users. Facebook has achieved around 2.74 billion active monthly users worldwide, followed by YouTube, Twitter, Instagram, TikTok, and so more (Kobiruzzaman, 2021).

Facebook is the most familiar social networking site among students, lecturers, business people, politicians, social workers, sportspeople, and unemployed people. Therefore, social media or new media have an adverse impact on traditional media. Nowadays, traditional media such as newspapers, television, radio, print, and banner media are confronting new challenges and new competitors due to the new media's progress, also known as social media. The average everyday circulation (print and digital combined) of United States newspapers decreased 8 per cent in 2018 and 2019, respectively (Pew Research Centre., 2019). Gradually, social media are taking over traditional media in precisely newspapers' positions because the alternative source of information and news in the new media is instant and accessible. Social media are an abundant source of information updated every few minutes where newspapers can provide news once a day.

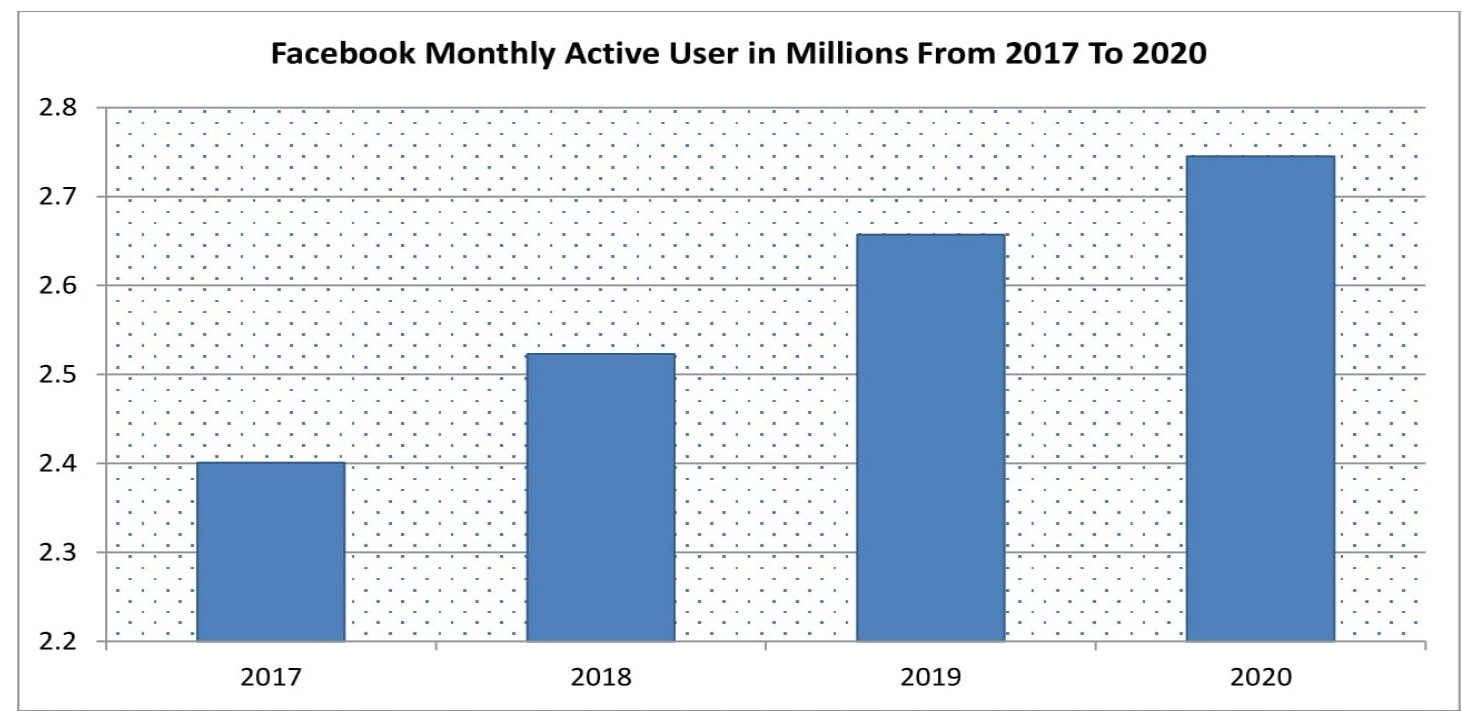

Figure 1. Facebook monthly active user in millions from 2017 to 2020 by (Kobiruzzaman 2021).

Note. This figure represents the overall increasing number of Facebook users from 2017 to 2020. Facebook monthly active user in millions.

Figure 1 represents that Facebook monthly active user was around 2.401 billion in $2017,2.523$ billion in 2018, 2.657 billion in 2019, and 2.745 billion in 2020 . According to agenda-setting theory, online news or social media reports will turn to a leading position, and traditional media will take the initiative to spread the agenda both offline and online (Harder, Sevenans, \& Van Aelst, 2017). In addition to agenda-setting theory, many other theories stated that the new media sneakily take over the ground of traditional media in order to increase demand for the assistant of news coverage (Dutta-Bergman, 2004). He also said that competition between traditional media social media is visible clearly, but traditional media is plumping daily. In contrast, in some countries, for example, India, traditional media such as newspapers remain a better position than social media in reading 
news (Maheshwar, \& Rao, 2011). The majority of Malaysian people have internet connections, and they read online newspapers to get the latest news every day (Salman et al., 2011).

The easy access to social media stimulates people in Malaysia to use them regularly. Traditional media, including TV, radio, and newspapers, face several challenges because of the excessive use of social media platforms. Netizens are highly dependent on new media, and they use these new media to get information (Husain et al., 2014). Therefore, newspapers have lost their subscribers dramatically in recent years. Recently, many newspaper agencies have terminated its operation; due to the social media revolution. Social media affect the closure of many traditional media all over the world. Utusan Malaysia, one of the oldest Malay-language newspapers in the country, was introduced on May 29 1939, and that had to terminate its operations because of the impact of social media (Mohamad Zaki \& Mohamed Sirad, 2019: Aliman, 2019, October 9). However, according to The Straits Times. (2020), Utusan Malaysia and its sister publication Kosmo! has come back on July 20, 2020, after nine months of the closure.

The research gaps obtained from previous literature have confirmed that only a few researches have been conducted in Malaysia on the topic. Additionally, most studies are conducted in the Malay language. Therefore, more studies on social media's impact on traditional media, especially on printed newspapers, can be conducted by focusing on these gaps. Therefore, this review paper's prime objective is to explore social media's impact on traditional media functions in Malaysia. Besides, this study will identify the impacts of social media-based citizen journalism on traditional media. Finally, the finding will discover the reasons for terminating the operation of the Utusan Malaysia newspaper.

\section{Methodology}

This review paper's findings are based on secondary sources of data collected by the content analysis in the systematic reviews method. Content analysis is the most used research approach in the social science research arena, including mass media, journalism, politics, and economics discipline(Weber (1990). According to Azazi \& Shaed (2020), the content analysis process of a review paper has four essential stages: 1) planning for reviewing the topic, 2) searching and gathering data from offline and online sources, 3) analysis and review the data, and 4) identifying and reporting the result of the study. Therefore, this study's content analysis was designed on open-access journal articles, university publication, statistic reports, books, newspaper articles, magazines, government archives, and internationally recognised non-government websites. The researcher has reviewed the literature from the government archive to find out the history of Utusan Malaysia and recent articles written on social media and its impact on traditional media.

In order to identify the relevant findings, the author uses the following keywords in the search engine: "social media and traditional media", " impact of social media on traditional media", "positive impacts of social media", " negative impacts of social media", "social media impact on printed newspaper", "social media impact on the closure of Utusan Malaysia", "political reason behind the closure of Utusan Malaysia" and "economic reason behind the closure of Utusan Malaysia" using the Google scholar, Web of Science, Emerald full text, and Malaysian online news portal. Many scholars have researched the issue of social media and its impact on traditional media. Few relevant results displayed in this review paper for better understanding. Based on previous research findings, the paper presented an integrative conceptual framework that describes the reasons behind Utusan

International Journal of Education and Knowledge Management (IJEKM) 
Malaysia's closure. Apart from that, each topic has been discussed elaborately for better understanding.

\section{Discussion and Results}

Nobody can deny social media's blessing to make our life more accessible from the viewpoint of interaction beyond the territorial boundary. New media have developed the communication process broadly. However, they have both positive and negative influences on society; therefore, it is called a double-edged sword. Facebook has been the leading social media among all other social media platforms available in Malaysia. Now, more than 90 per cent of teenagers use smartphones (Kobiruzzaman, 2021), and in the meantime, most of them browse social media regularly to consume news and information (Hayati et al., 2012). People get benefited from using social media for education, communication, work from home and marketing purposes. (Anderson \& Jiang, 2018). On the other hand, social media's adverse effects are cyberbullying, hacking, addiction, and spreading fake news (Kobiruzzaman et al., 2018).

\section{Positive Impacts of Social Media}

In research from Ho (2019), in Malaysian, social media users spend average five hours a day on soical media platforms. People are not interested in reading newspapers to get information as social media providing information in real-time. Social media's positive effects on society are imparting knowledge, accelerating the communication process, building a virtual workplace, e-commerce and marketing.

Firstly, social media, including Facebook, WhatsApp, Instagram, Twitter, have become vital platforms to impart knowledge and share information. Students use these social media to conduct group studies (Kobiruzzaman, 2021). The lecturer and instructor influence students to involve with social media platforms to earn more knowledge from group discussions.

Social media are the best online-based channel to impart knowledge and share information (Yang \& Lee, 2018). In the COVID-19 Pandemic, educators and students have comprehended that how much difficult education would be without obtaining social media sites such as Google Meet, Zoom and so more. New media sites are the most helpful technology for sharing information and imparting knowledge. Ghazali and Omar (2015) mentioned that social media based-news had become a leading learning medium for young general. The new media allow people to conduct interactive communication with instant feedback (Alivi, Ghazali, Tamam, \& Osman, 2018). Therefore, people prefer to use social media to maintain effective communication via video calling to talk to a beloved person far from their location.

Apart from that, social media has accelerated the process of communication via mediated communication. Nowadays, people are using social media platforms such as WhatsApp, Facebook, and Instagram to communicate with friends, family, followers, and colleagues. These platforms are easy to use and inexpensive to afford. (Ling, 2016). The COVID-19 Pandemic has changed the working environment and employee has experienced a remote working condition. The world health organization (WHO) requested to imposed a countrywide lockdown to combat the Coronavirus. The COVID-19 Pandemic has changed people's lifestyles, education, norm, and the world economy dramatically. In Malaysia, the government imposed the first movement control order (MCO) from March 18 2020, to March 31 in the same year (Zolkepli, 2020, March 16). The government also 
instructed to shut down all government, semi-government, and non-government organizations to stop spreading the Coronavirus. Apart from other organizations, the public and private universities conduct virtual classes via social media platforms, including Zoom, Google classroom, Webinar, and so more. Students might not encounter session jams because of participating in virtual classes.

Many organizations use different social media platforms to conduct organizational activities, especially handling virtual meetings (Phillips \& Young, 2009). Furthermore, the E-commerce marketing process has been emerged due to the social media revolution. Ecommerce means an electronic marketing strategy that allows people to buy and sell products through the internet (Mahadevan, 2000). E-commerce sites adopt social media platforms to target audience segmentation as well as sell product. Most renowned companies utilize their verified social media pages and account for organizational branding. Although, in previous, women use social media platforms more than men to buy the necessary product. In the COVID-19 Pandemic, both men and women depend on the ecommerce site to buy products ( $\mathrm{Li}$, Hallsworth, \& Coca-Stefaniak, 2020). Urban people and rural people have adopted social media-based e-commerce sites to sell and buy products.

\section{Negative Impacts of Social Media}

According to Li (2006), many teenagers have been associated with criminal activities through new media, for example, cybersecurity and cyberbullying. Kobiruzzaman et al., (2018) mentioned the most significant adverse impacts of social media are cyberbullying, hacking, addiction, and spreading fake news.

Firstly, cyberbullying means harassing someone via online platforms such as Blogsite, Facebook, Instagram, WhatsApp, and Web-portal (Kiriakidis \& Kavoura, 2010). Therefore, cyberbullying is also known as online buying or cyber harassment. According to Kobiruzzaman (2021), in Malaysia, most teenagers are affected by cyberbullying using social media platforms. Cyber harassment occurs by spreading someone's personal information, such as personal message, photo, and video. The scholar has identified that social media trigger people directly or indirectly to bully others online (Ghazali, Omar, Ahmad, Samah, Abdullah, Ramli, \& Shaffril, 2016). Teenagers are indulged in this crime through electronic devices such as smartphones, computers, tablets, and laptops. People bully others through text messages, photos, and video content on social media. Additionally, hacking has been increased because of a social media revolution. The new social media user keeps their personal information without paying attention to privacy and security issues. Usually, hackers lure victims to disclose private information on social media. After that, they leak and publish those personal information on social media sites.

Furthermore, the most terrifying adverse affect of new media on society is addiction that has been a worsened phenomenon among teenagers. Around 220 million new media user are addicted to new media directly or indirectly (Hawi \& Samaha 2017). A study revealed that around $71 \%$ of American people keep their smartphones while sleeping at night, and they are addicted to social media (Kobiruzzaman, 2021). Finally, Social media are being used to spread fake news. Fake news spreading has been increased during the COVID -19 pandemic (Apuke \& Omar, 2020; Rashid, 2020). Many people spread fake news or rumors intentionally to promote something or defame some things (Ajao, Bhowmik, \& Zargari, 2019). Internet-based technology allows people to spread fake and 
fabricated news with anonymity. In Malaysia, the spreading of fake news on social media regarding COVID-19 has risen excessively (Apuke \& Omar, 2020).

\section{Utusan Malaysia}

Utusan Melayu is the former name of Utusan Malaysia. Utusan Malaysia is a prominent Malay-language daily newspaper that was first launched on May 29 1939, as Utusan Melayu owned by Utusan Melayu Press Limited (UMPL) (The Straits Times, 2020, July 20; Zack, 2019, August 19). Utusan Group is the parent company of the Utusan Malaysia newspaper (Sukumaran, 2019). It was the oldest newspaper that initially started to publish in Jawi and Arabic script. It started the operation from its head office at 64 Queen Street in Singapore (Chia, 2007, June 12). It stopped circulation during the Japanese invasion of Malaya. According to Singapurastories. (2014), in 1945, Utusan Melayu shifted its office to 185 Cecil Street in Singapore, and it conducted its operation from this office during the critical post-war times of 1945 to 1958 . However, in February 1958, the head office of Utusan Melayu has shifted again to $46 \mathrm{M}$, Jalan Lima, Kuala Lumpur in Malaysia (Sundara Raja, Rajasakran, \& Sinnappan, 2013). Consequently, on August 30 1964, a new weekly edition of Utusan Melayu had issued as the name Mingguan Malaysia from its Kuala Lumpur office (Sundara Raja et al., 2013). On September 1 1967, Utusan Melayu produced the first romanised version as Utusan Malaysia, the daily edition (The Straits Times, 2020, July 20).

The main purpose of this newspaper was to protect the Malay people's rights at the British regime. Originally, Utusan Malaysia was founded by Yusof Ishak and Abdul Rahim Kajai before the independence of Malaysia. Later, Yusof Ishak became the first president of Singapore in 1959, and Abdul Rahim Kajai became one of the most familiar people in the Malay journalism arena, also called the father of Malay journalism (Chia, 2007). Utusan Melayu and Utusan Zaman both were the leading newspapers in Malaysia since launching the operation.

The Federation of Malaya got independent on August 311957 (Sulam et al., 2018), whereas Utusan Malaysia launched its operation in 1939 (Zack, 2019). This newspaper started its journey 18 years before Malaya got independence in 1957, and 24 years earlier, the Federation of Malaysia was formed in 1963 (Zack, 2019). The paper was started its journey with a small capital of RM around 12,000 (US\$3,726). In a short time, it became a well-known platform for many famous writers, for example, Abdul Samad Ismail, Zaba, Usman Awang, and Abdul Rahim Kajai. This newspaper provided its opinion on many national issues. It urged the Malay leaders not to sign Malayan Union and request the Malays to stay united against the proposal. In 1946, It also contributed to forming the United Malay National Organisation (UMNO) (Sundara Raja et al., 2013).

However, this renowned newspaper had stopped its operations on October 92019 , after 80 years of survival (Palansamy, 2019). Apart from the closure of the Utusan Malaysia, the authority announced to shut down the Kosmo also Utusan's sister's weekly publication that was launched in 2004. Utusan Malaysia confronted a crucial business period when its daily circulation and readers continually declined. According to (Zack 2019), in 2019, the authority had chosen a "do-or-die" option as they increased the price of Utusan Malaysia's newspaper by 50 SEN to RM2 in August 2019. Along with that, they also increased the price for Kosmo to RM1.50 at the same time. This policy could not protect them from the closure of the operation. Finally, they decided to cease their 
operation when the cash flow began to deteriorate. The management cited that they are liquidating the company, but they will come back soon.

Media Mulia Sdn Bhd has currently owned Utusan Malaysia (Zack, 2019). On July 20, 2020, Utusan Malaysia and its sister publication Kosmo! has come back after nine months of the closure (The Straits Times., 2020). Utusan Malaysia used to be regulated by UMNO, but it decided to cease its operation due to poor financial conditions. It is estimated that more than 800 workers lost their job without paying a pending salary (The Straits Times., 2020).

\section{Reasons Behind the Closure of the Utusan Malaysia}

Based on the information collected from secondary data, the author has presented three factors that trigger the shut off of the Utusan Malaysia newspaper: poor financial conditions, political issues, and social media. These factors are interconnected, and they influenced to cease of its operation directly and indirectly. Based on the previous research, the three vital influencers of Utusan Malaysia's closure are the poor financial condition, political issues, and the emergence and influence of social media in Malaysia.

\section{Poor Financial Conditions}

The prolonged economic crisis of Utusan Malaysia compelled it to cease the operation altogether. Utusan Malaysia's authority declared they cannot overcome its financial crisis; therefore, they decided to stop publishing (Rahim, \& Lajim, 2019). Many employees, including administrative officials, journalists, photographers, and graphic artists, demonstrated a protest outside the company's head office for their outstanding wages and severance payments (Jayne, 2019). Although Utusan Malaysia was one of the leading selling newspapers in Malaysia, it has been forced to shut down its operation for poor financial conditions quickly. In the 1990s, they managed to circulate 350,000 copies a day, and in 2002, Utusan Malaysia won the award of the "IFRA Publish Asia 2003 Award" for the category of the "Best in Print". (The AsiaN., 2019). According to Malay Mail, after unable to pay around RM1.2 million outstanding debts to two banks, the Utusan Group has PN17 status on the Malaysian Stock Exchange (Palansamy, 2019; Mohamad Zaki \& Mohamed Sirad, 2019). Datuk Abd Aziz Sheikh Fadzir, also executive chairman of Utusan, had announced that declining sales, poor cash flow, and mounting debts directed the board to decide to shut down its operations (Murugiah, 2019).

\section{Political Issues}

Apart from poor economic conditions, the political issue also affected the closure of the prominent newspaper Utusan Malaysia. The United Malays National Organization (UMNO), Malaysia's most prominent and leading political party, owns a 19 per cent stake in the Utusan Group. In the 1950s, UMNO members started to buy Utusan Melayu's share when the Malay nationalistic unrest spread (Chia, 2007). In the meantime, most journalists, including Utusan Melayu, expressed anti-British attitudes. Nonetheless, the early Malays nationalism movement separated people into two groups, for example, people who support to formation Federation of Malaya, where the Sultan is the head of state, and people who favor abolishing the sultans and leading in a republic. The political party UMNO supported to formation Federation of Malaya, where the Sultan is the head of state. UMNO changed its publication policy from an independent paper to their party's paper when they took over the Utusan Melayu major shareholder. However, they had to change the policy from 
political party newspaper to freedom paper due to the employees' three-month strike. Finally, UMPL moved its office from Singapore to Kuala Lumpur in Malaysia in 1958 (Chia, 2007, June 12). United Malays National Organization (UMNO) ruled the country from the independence of Malaysia in 1957 to 2018 (Baharin, Waheed, Ghazali, \& Ahmad, 2020); Moniruzzaman, \& Farzana, 2018). At the same time, UMNO patronized Utusan Malaysia politically and financially until defeated by the Pakatan Harapan in the 2018 national election. The paper lost the political influence of the UMNO after the 2018 election. Datuk Seri Dr Ahmad Zahid Hamidi, also the president of the UMNO, told the press media that Umno is not able to support the cash-strapped Utusan Melayu (Malaysia) Berhad because the Pakatan Harapan administration has frozen its accounts for being involved in the 1MDB scandal (The Star TV., 2019). Therefore, Utusan Malaysia decided to stop its operation due to UMNO's poor financial condition and political crisis.

\section{Social Media}

The emergence and evolution of social media in Malaysia and the rising citizen journalism practicing indicate a prime reason behind Utusan Malaysia's closure. Social media are much more advanced than traditional media in sports and entertainment; the audience can watch live events through social media such as Facebook, YouTube, Instagram, and so more (Woodcock \& Johnson, 2019). A study conducted among 100 respondents proposed that an enormous amount of 42 per cent of the respondents like to read worldwide news from social media. Simultaneously, 24 per cent depends on the website, 20 per cent go for television channel, 8 per cent with smartphone applications, only 4 per cent read newspapers, and 2 per cent chose radio stations (Wangde, 2018). People can see the political announcements on social media platforms often faster than any traditional news outlet. Nowadays, vertical media is experiencing a rapid decline in social media platforms' growth (Robinson, 2019). Ismail, Ahmad, Noor, and Saw (2019) mentioned that around 80 per cent of Malaysian youth utilize social media, such as Facebook, WhatsApp, Twitter, and Instagram, to consume news and share opinions. Many newspapers cut editorial content and sack staff because of plunging circulation and falling ad revenues (Bassey, 2006).

The lower circulation and cutting editorial content of Utusan Malaysia trigger to loss of the ad revenues. So, the lower circulation is the leading cause of reducing the selling of the Utusan Malaysia newspaper copies, and it triggers to decrease in the daily income. The commercial company became uninterested in displaying their print ads in the newspaper because people do not read them (Kelly, Kerr \& Drennan, 2010). They chose social media marketing (SMM) platforms to brand the products. Thus, the newspaper company reduces its income and getting poor cash flow and mounting debts. The social media revolution in Malaysia declined the subscribers of the printed newspaper and the Utusan Malaysia, and finally, it spurred the revenue of the paper. Therefore, the authority of Utusan Malaysia shut down its circulation on October 9 2019. However, Malaysia's most traditional Malay language publication Utusan Malaysia and its sister publication Kosmo! has come back on July 20, 2020, after a nine-month shutdown" (The Straits Times., 2020).

The following Figure 2 has been decorated based on the previous research. This model might help identify social media's factors and impacts on traditional media, especially on printed newspapers. Based on the study's finding, the suggestion has been described to help the traditional media survive in the digital era. This paper may contribute

International Journal of Education and Knowledge Management (IJEKM) 
to future research to identify the decline in the audience or subscribers of the traditional media such as TV, Radio, Newspapers, and magazines.

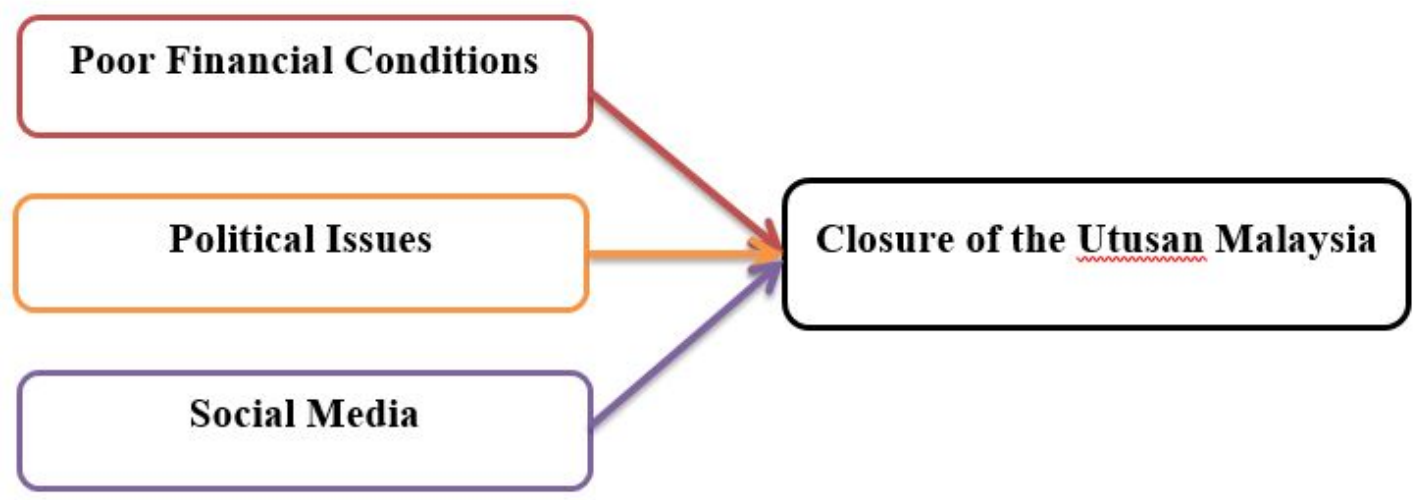

Figure 2. Conceptual Model of Reasons Behind the Closure of the Utusan Malaysia

\section{Conclusion}

Social networking platforms have both advantages and disadvantages influences on society. People optimize social media to obtain knowledge, communicate other, create a virtual workplace, and e-commerce marketing. In contrast, some misusers are indulged with cybersecurity, cyberbullying, hacking, and spreading fake news. The new generation in Malaysia prefers social media to traditional media to share information and consume news.

Jalli (2020) argued that Malaysian people use social media platforms to practice citizen journalism due to extreme control over Mainstream media. Therefore, people are sceptical of the information disseminated by the traditional media such as TV, Radio, and Newspapers. Citizen journalists work for general people's rights. Hence, audiences consume news from social media. The practice of citizen journalism in Malaysia has been increased due to social media platforms' availability (Jalli, 2020). Hence, many newspaper companies are losing their consumers because of the social media revolution. Utusan Malaysia collapsed for poor economic conditions, political issues, and social media, although it has re-launched again. Traditional media should follow alternative ways to retain consumers connected with them, such as regulating social media pages for traditional media and publishing news in both print and online versions. Nowadays, most newspaper companies are publishing both online and offline versions of news articles. They set monthly and yearly subscription options for readers who can read news from an online newspaper portal by paying money through a subscription policy.

Mainstream media play the mouthpiece role in the Malaysian ruling government (Salman et al., 2011). Media practitioners cannot practice independently thinking that the content tarnishes the government's image and the country. Therefore, people are skeptical about the information and message broadcasted through traditional media such as Television, Radio, newspapers, and magazines. The mainstream media have to work for protecting the rights of the general people.

In Malaysia, youth have minimal opportunity to share ideas through traditional media outlets such as television, radio, newspapers, and magazines (Mahamed \& Omar, 2017). Hence, youth in Malaysia are involved in practicing social media-based citizen 
journalism to share ideas and information. Traditional media need to allocate scope for the young generation to share their ideas through them. Finally, to survive the printed newspaper company in the digital era, it has to adjust with both offline and online templates to disseminate news. People prefer more to consume real-time news via online platforms.

\section{Limitations and Direction for Future Research}

This article has been generated based on the secondary data analysis approaches. The author has not utilized the primary data collection process in order to collect information relevant to the study. Therefore, it is a crucial limitation of the study. However, the findings of the study will certainly contribute to reducing the literature gap. The author has collected data from authentic sources, including the research paper, books, and government websites. So, the data can be used in future research.

\section{References}

Ajao, O., Bhowmik, D., \& Zargari, S. (2019, May). Sentiment aware fake news detection on online social networks. In ICASSP 2019-2019 IEEE International Conference on Acoustics, Speech and Signal Processing (ICASSP) (pp. 2507-2511). IEEE.

Aliman, K. H. (2019, October 9). "Utusan will live on," says executive chairman. The Edge Markets. https://www.theedgemarkets.com/article/utusan-will-live-saysexecutive-chairman

Alivi, M. A., Ghazali, A. H. A., Tamam, E., \& Osman, M. N. (2018). A review of new media in Malaysia: Issues affecting society. International Journal of Academic Research in Business and Social Sciences, 8(2), 12-29.

Anderson, M., \& Jiang, J. (2018). Teens, social media \& technology 2018. Pew Research Center, 31(2018), 1673-1689.

Apuke, O. D., \& Omar, B. (2020). Fake news and COVID-19: modelling the predictors of fake news sharing among social media users. Telematics and Informatics, 56, 101475.

Azazi, N. A. N., \& Shaed, M. M. (2020). Social Media and Decision-Making Process among Tourist: A Systematic Review. Jurnal Komunikasi: Malaysian Journal of Communication, 36(4).

Baharin, M. I., Waheed, M., Ghazali, A. H. A., \& Ahmad, A. M. T. (2020). Framing Analyses of Malaysia's Media Outlets and Editorial Decisions Concerning Frame Preferences after the 2008 General Election. Pertanika Journal of Social Sciences \& Humanities, 28(2).

Baruah, T. D. (2012). Effectiveness of Social Media as a tool of communication and its potential for technology-enabled connections: A micro-level study. International journal of scientific and research publications, 2(5), 1-10.

Bassey, E. A. (2006). The rise and fall of ThisDay newspaper: The significance of advertising to its demise (Doctoral dissertation).

Chia, J. Y. J. (2007, June 12). Utusan Melayu | Infopedia. Https://Eresources.Nlb.Gov.Sg/. https://eresources.nlb.gov.sg/infopedia/articles/SIP 1088_2007-06-12.html

Dutta-Bergman, M. J. (2004). Complementarity in consumption of news types across traditional and new media. Journal of broadcasting \& electronic media, 48(1), 4160. 
Ghazali, A. H. A., \& Omar, S. Z. (2015). Mobile News: What Kind of Information Needed by the Youth? Journal of Media Critiques [JMC], 1(4).

Ghazali, A. H. A., Omar, S. Z., Ahmad, A., Samah, A. A., Abdullah, H., Ramli, S. A., \& Shaffril, H. A. M. (2016). Potential personality traits that explain cyberbullying among youth in Malaysia. International Journal of Academic Research in Business and Social Sciences, 6(12), 741-749.

Giddens, A. (2018). Globalisation. In Sociology of Globalisation (pp. 19-26). Routledge.

Haddon, L. (2004). Information and communication technologies in everyday life: A concise introduction and research guide (pp. 62-63). Oxford: Berg.

Harder, R. A., Sevenans, J., \& Van Aelst, P. (2017). Intermedia agenda-setting in the social media age: How traditional players dominate the news agenda in election times. The International Journal of Press/Politics, 22(3), 275-293.

Hawi, N. S., \& Samaha, M. (2017). The relations among social media addiction, selfesteem, and life satisfaction in university students. Social Science Computer Review, 35(5), 576-586.

Hayati, A. G. A., Zobidah, o. s., Jusang, b., Nizam, o. m., \& Mazuwana, m. t. t. (2012). Newspapers: Teenagers and Their Needs. The Public Administration and Social Policies Review. 1 (8), 113, 124.

Ho, K. (2019, April 30). Malaysians spend almost a quarter of their day on social media. YouGov: What the World Thinks. https://my.yougov.com/enmy/news/2019/04/30/malaysians-spend-almost-quarter-their-day-social-m/

Husain, K., Abdullah, A. N., Ishak, M., Kamarudin, M. F., Robani, A., Mohin, M., \& Hassan, S. N. S. (2014). A preliminary study on effects of social media in crisis communication from public relations practitioners' views. Procedia-Social and Behavioral Sciences, 155, 223-227.

Ismail, N., Ahmad, J., Noor, S. M., \& Saw, J. (2019). Malaysian Youth, Social Media Following, and Natural Disasters: What Matters Most to Them? Media Watch, 10(3), 508-521.

Jalli, N. (2020). Exploring the influence of citizen journalism content on the Malaysian political landscape. Kajian Malaysia: Journal of Malaysian Studies, 38(1).

Jayne, T. (2019, August 20). Here Is Why The Country's Oldest Newspaper Utusan Malaysia May Be Shutting Down Tomorrow. SAYS. https://says.com/my/news/here-s-why-utusan-malaysia-may-be-shutting-downtomorrow

Kelly, L., Kerr, G., \& Drennan, J. (2010). Avoidance of advertising in social networking sites: The teenage perspective. Journal of interactive advertising, 10(2), 16-27.

Kiriakidis, S. P., \& Kavoura, A. (2010). Cyberbullying: A review of the literature on harassment through the internet and other electronic means. Family \& community health, 33(2), 82-93.

Kobiruzzaman, M. M., Waheed, M., Yaakup, H. S. B., \& Osman, M. N. (2018). Impact of Social Media Towards Society, A Case Study on Teenagers. International Journal of Education and Knowledge Management 1(3), 1-12. https://doi.org/10.37227/IJEKM-03-2018-14

Kobiruzzaman, M. M. (2021). Role of Social Media in Disaster Management in Bangladesh Towards the COVID-19 Pandemic: A Critical Review and Directions. International Journal of Education and Knowledge Management (IJEKM) 4(2), 114. https://doi.org/10.37227/IJEKM-2021-03-39 
Li, J., Hallsworth, A. G., \& Coca-Stefaniak, J. A. (2020). Changing grocery shopping behaviours among Chinese consumers at the outset of the COVID-19 outbreak. Tijdschrift voor economische en sociale geografie, 111(3), 574-583.

Li, Q. (2006). Cyberbullying in schools: A research of gender differences. School psychology international, 27(2), 157-170.

Mahadevan, B. (2000). Business models for Internet-based e-commerce: An anatomy. California management review, 42(4), 55-69.

Mahamed, M., \& Omar, S. Z. (2017). Citizen Journalism Role in Promoting Cultural Integration and Peace in Malaysia. International Journal of Academic Research in Business and Social Sciences, 7(8), 673-680

Maheshwar, M., \& Rao, R. D. (2011). A comparative analysis of nutrition science coverage by popular Indian daily newspapers. Journal of Media and Communication Studies, 3(4), 131-143.

Mohamad Zaki, Q. A. M., \& Mohamed Sirad, S. N. (2019). The determinants of financial performance of PN17 company in Malaysia: a case study of Utusan Melayu (Malaysia) Berhad.

Moniruzzaman, M., \& Farzana, K. F. (2018). Malaysia'14th General Election: End of an epoch, and beginning of a new? Intellectual Discourse, 26(1), 207-228.

Murali, R. (2020, June 21). Utusan Malaysia, Kosmo! expected to return next month. The Star Online. https://www.thestar.com.my/news/nation/2020/06/21/utusan-malaysiakosmo-expected-to-return-next-month

Murugiah, S. (2019, October 9). Utusan Melayu ceases operations. The Edge Markets. https://www.theedgemarkets.com/article/utusan-melayu-ceases-operations

Obar, JA and Wildman, S. (2015). Social media definition and the governance challenge: An introduction to the special issue. Telecommunications policy, 39(9), 745-750.

Palansamy, Y. (2019, October 13). Utusan Malaysia shuts down. Malaysia| Malay Mail. https://www.malaymail.com/news/malaysia/2019/10/09/utusan-malaysia-shutsdown $/ 1798567$

Phillips, D., \& Young, P. (2009). Online public relations: A practical guide to developing an online strategy in the world of social media. Kogan Page Publishers.

Pew Research Centre. (2019, July 9). Newspapers Fact Sheet. Pew Research Center's Journalism Project. https://www.journalism.org/fact-sheet/newspapers/

Rahim, S., \& Lajim, F. (2019, October 10). Utusan officially closes its doors. NST Online. https://www.nst.com.my/news/nation/2019/10/528302/utusan-officially-closes-itsdoors

Rashid, A. (2020, March 30). Coronavirus: Celebrities Are Helping COVID-19 Misinformation Go Dangerously Viral Online. NDTV Gadgets 360. https://gadgets.ndtv.com/social-networking/features/coronavirus-covid-19celebrities-spreading-misinformation-social-media-twitter-facebook-whatsapp2202851

Robinson, G. (2019). Mass Communication and Journalism. Scientific e-Resources.

Salman, A., Ibrahim, F., Abdullah, M. Y. H., Mustaffa, N., \& Mahbob, M. H. (2011). The impact of new media on traditional mainstream mass media. The Innovation Journal: The Public Sector Innovation Journal, 16(3), 1-11.

Singapurastories. (2014). Utusan Melayu Cecil St SG 1945-58. http://singapurastories.com/merdeka-singapores-merdeka-talks-of-1956-and-1957- 
and-merdeka-proclamations-of-1959-1962-and-1963/utusan-melayu-cecil-st-sg1945-58/

Statista (2018). Most famous social network sites worldwide as of October 2018, ranked by number of active users (in millions).https://www.statista.com/statistics/272014/global-social-networks-rankedbynumber-of-users/.

Sukumaran, T. (2019, October 9). Umno-linked Utusan Malaysia newspaper shuts down after 80 years. South China Morning Post. https://www.scmp.com/weekasia/politics/article/3032166/umno-linked-utusan-malaysia-newspaper-shuts-downafter-80-years

Sulam, M., Zamri, N. A. K., \& Merican, A. M. (2018). The Consciousness of History in Malaysia: The Ideas on Merdeka Day in Sarawak. In SHS Web of Conferences (Vol. 53, p. 02006). EDP Sciences.

Sundara Raja, S., Rajasakran, T., \& Sinnappan, S. (2013). Malaysia's Hindu rights action force (Hindraf): a perspective from a Malay mainstream daily. International Journal of Academic Research, 5(5).

The AsiaN. (2019). Sad day for journalism as Utusan Malaysia ceases publication THEAsiaN. Http://Www.Theasian.Asia. http://www.theasian.asia/archives/106366

The Star TV. (2019, October 9). Zahid says frozen Umno accounts cause Utusan's closure. TheStarTV.Com. https://www.thestartv.com/v/zahid-says-frozen-umno-accountscause-utusan-s-closure

The Straits Times. (2020, July 20). Malaysia's oldest Malay language newspaper Utusan is back after a nine-month shutdown. https://www.straitstimes.com/asia/seasia/malaysias-oldest-malay-language-newspaper-utusan-is-back-after-nine-monthshutdown

Wangde, A. (2018, February 14). People Prefer Digital Over Print for News \& Views. AM Marketing, Media, Advertising News in MENA. https://arabianmarketer.ae/peopleprefer-digital-print-news-views/

Weber, R. P. (1990). Basic content analysis (No. 49). Sage.

Woodcock, J., \& Johnson, M. R. (2019). Live streamers on Twitch. tv as social media influencers: Chances and challenges for strategic communication. International journal of strategic communication, 13(4), 321-335.

Zack, J. (2019, August 19). Utusan, oldest Malay newspaper, and Kosmo! to cease publication. The Star Online. https://www.thestar.com.my/news/nation/2019/08/19/utusan-malaysias-oldestnewspaper-and-kosmo-to-cease-publication

Zolkepli, F. (2020, March 16). Malaysia announces movement control order after spike in Covid-19 cases (updated). The Star Online. https://www.thestar.com.my/news/nation/2020/03/16/malaysia-announcesrestricted-movement-measure-after-spike-in-covid-19-cases 


\section{Biodata of Authors}

M M Kobiruzzaman is an international student at the department of communication in Universiti Putra Malaysia. His research interest areas include journalism, human communication, mass media, and social media. He is also a part-time content writer at Newsmoor.com, an educational website. Email: mmkobiruzzaman@gmail.com

Akmar Hayati Ahmad Ghazali (PhD) is an Associate Professor in Communication Department, Universiti Putra Malaysia. She is also Head of Cyber Generation Laboratory at IPSAS UPM. Email: akmar@upm.edu.my 